\title{
STUDYING THE REACTION ROUTE OF $\alpha, \beta$-DIBROMO KETONE AT PRESENCES OF SOME AMINES
}

\section{G. Mamedov ${ }^{a^{*}}$, I. M. Shikhaliyeva ${ }^{a}$, Y. V. Mamedova ${ }^{a}$}

${ }^{a}$ Baku State University, Faculty of Chemistry, akad. Z. Khalilov street 23, Baku, Azerbaijan, bsu.nmrlab@mail.ru

a-Bromo-chalcone with containing thiene ring by the reaction of selective dehydrobromination of $\alpha, \beta$-dibromo ketone at presences of different amines in benzene solution and $\alpha$-ethoxy- $\beta$-bromo-ketone in ethanolic solution in good yields were prepared. $\alpha, \beta$-Dibromo ketone with the reaction of thiosemicarbazide lead to the formation of new pyrazole derivative.

Keywords: acetophenone, chalcone, $\alpha, \beta$-dibromo ketone, pyrazole.

INTRODUCTION. The acetophenones, their chalcone, $\alpha, \beta$-dibromo ketone derivatives are important compounds in chemistry and are valuable synthetic building blocks in synthesis of various heterocyclic compounds. $\alpha, \beta$-Dibromo ketones are useful synthons in the synthesis of a large number of pyrazolines, pyrazolines, isoxazoles etc [1-11].

Due to their different functionality these compounds confer biological activities, such as antimicrobial, antibacterial, antifungal, anticancer, antitubercular, antiviral, antiinflammatory, antihyperglycemic, and etc [12-17].

This work the reaction route of $\alpha$, $\beta$-dibromo ketone at the presence of some amines had been studied.

EXPERIMENT AND DISCUSSION OF RESULTS. All the chemicals were obtained from commercial sources (Aldrich) and used as received.
NMR experiments have been performed on a BRUKER FT NMR spectrometer (UltraShieldTM Magnet) AVANCE 300 (300.130 MHz for ${ }^{1} \mathrm{H}$ and $75.468 \mathrm{MHz}$ for ${ }^{13} \mathrm{C}$ ) with a BVT 3200 variable temperature unit in $5 \mathrm{~mm}$ sample tubes using Bruker Standard software (Topspin 3.1). The ${ }^{1} \mathrm{H}$ and ${ }^{13} \mathrm{C}$ chemical shifts were referenced to internal tetramethylsilane (TMS); the experimental parameters for ${ }^{1} \mathrm{H}$ : digital resolution $=0.23 \mathrm{~Hz}, \mathrm{SWH}=7530 \mathrm{~Hz}$, $\mathrm{TD}=32 \mathrm{~K}, \mathrm{SI}=16 \mathrm{~K}, 90^{\circ}$ pulse-length $=10 \mu \mathrm{s}$, $\mathrm{PL} 1=3 \mathrm{~dB}, \mathrm{~ns}=1, \mathrm{ds}=0, \mathrm{~d} 1=1 \mathrm{~s}$; for ${ }^{13} \mathrm{C}$ : digital resolution $=0.27 \mathrm{~Hz}, \mathrm{SWH}=17985 \mathrm{~Hz}$, $\mathrm{TD}=64 \mathrm{~K}, \mathrm{SI}=32 \mathrm{~K}, 90^{\circ}$ pulse-length $=9 \mu \mathrm{s}$, PL1 $=1.5 \mathrm{~dB}, \mathrm{~ns}=100, \mathrm{ds}=2, \mathrm{~d} 1=3 \mathrm{~s}$ (Figure S1-S5). NMR-grade DMSO-d 6 (99.7\%, containing $0.3 \% \mathrm{H}_{2} \mathrm{O}$ ) and $\mathrm{CDCl}_{3}$ were used for the solutions of $3-7$.

The purity of the synthesized compounds was confirmed by thin-layer chromatography 
(TLC) on commercial aluminum-backed plates of silica gel (60 F254), iodine vapor was used as visualizing agent, eluent- 5:2 hexane/ ethyl acetate.

Melting points were measured on an Electrothermal 9100 apparatus without correction.

The procedure for syntheses of chalcone

To a solution of thiophene-2-carboxaldehyde (1) (5 mmol) and 4-bromoacetophenone (2) $(5 \mathrm{mmol})$ in $\mathrm{EtOH}(20 \mathrm{ml})$, an aqueous solution of sodium hydroxide $(\mathrm{NaOH})(5 \%$, $5 \mathrm{ml}$ ) was added. The temperature was kept at $25^{\circ} \mathrm{C}$ and the mixture was stirred vigorously for 3-4 h. Then, it was neutralized with aqqueous $\mathrm{HCl}$. The mixture was added to $50 \mathrm{~g}$ ice. The solid product was separated by filtration and the residue purified by crystallization from mixture of carbon-4-chloride and hexane 1:1.

(E)-1-(4-Bromophenyl)-3-(thien-2-yl)prop2-en-1-one (3). Yellow crystals, yield 87\%, mp $133-135{ }^{\circ} \mathrm{C}[10]$.

The procedure for syntheses of $\alpha$, $\beta$-dibromo ketone

To a stirred solution of chalcone (3) $5 \mathrm{mmol}$ ) in $25 \mathrm{ml}$ of $\mathrm{CH}_{2} \mathrm{Cl}_{2}$ was added solution of bromine $(5 \mathrm{mmol})$ in $5 \mathrm{ml}$ of $\mathrm{CH}_{2} \mathrm{Cl}_{2}$ at $25^{\circ} \mathrm{C}$. The mixture was stirred for $1-2 \mathrm{~h}$ at room temperature. The solid product was separated by filtration and purified by crystallization from a mixture of of carbon-4-chloride and hexane 1:1.

2,3-Dibromo-1-(4-bromophenyl)-3-(thiophen-2-yl)propan-1-one (4). Colorless crystals, yield, $77 \%, \mathrm{mp} 138-139{ }^{\circ} \mathrm{C}$ [11].

The procedure for syntheses of $\alpha$-ethoxy- $\beta$ bromo-ketone and $\alpha$-bromo chalcone

a) To a solution of dibromo chalcone (4) ( $1 \mathrm{mmol})$ in $\mathrm{CH}_{3} \mathrm{CH}_{2} \mathrm{OH}(20 \mathrm{ml})$ was added triethylamine $(1 \mathrm{mmol})$ and ethylenediamine ( $1 \mathrm{mmol})$. The mixture was stirred at the reflux temperature of ethanol for $3 \mathrm{~h}$. After comple- tion of the reaction, the mixture was added to $50 \mathrm{~g}$ ice, the solid product was separated by filtration and the residue purified by crystallization from a mixture of carbon-4-chloride and hexane $1: 1$.

(2E)-2-bromo-1-(4-bromophenyl)-3-ethoxy3-(thiophen-2-yl)prop-2-en-1-one (5). Yellow crystals, yield $87 \%, \mathrm{mp} 165-168{ }^{\circ} \mathrm{C}$ (diastereomic mixture). ${ }^{1} \mathrm{H} \mathrm{NMR}\left(\mathrm{CDCl}_{3}, 300 \mathrm{MHz}\right): \delta_{\mathrm{H}}$ 6.89-7.3 (3H, m, $\left.\mathrm{C}_{4} \mathrm{H}_{3} \mathrm{~S}\right), 7.56$ and $7.9(4 \mathrm{H}, \mathrm{d}$, $\left.\mathrm{C}_{6} \mathrm{H}_{4}, \mathrm{~J} 9.0 \mathrm{~Hz}\right), 5.24(1 \mathrm{H}, \mathrm{d}, \mathrm{J} 9.0 \mathrm{~Hz}, \mathrm{CH}), 5.09$ $(1 \mathrm{H}, \mathrm{d}, \mathrm{J} 9.0 \mathrm{~Hz}, \mathrm{CH}), 3.50(2 \mathrm{H}, \mathrm{k}, \mathrm{J} 6.0 \mathrm{~Hz}$, $\left.\mathrm{CH}_{2}\right), 1.04\left(3 \mathrm{H}, \mathrm{t}, \mathrm{J} 6.0 \mathrm{~Hz}, \mathrm{CH}_{3}\right) .{ }^{13} \mathrm{C} \mathrm{NMR}$ $(\mathrm{CDCl} 3,75 \mathrm{MHz}): \delta_{\mathrm{C}} 191.55,133.33,132.16$, $131.86,130.07,129.08,127.78,126.59,126.08$, 65.41, 48.02, 14.99 .

${ }^{1} \mathrm{H}$ NMR $\left(\mathrm{CDCl}_{3}, 300 \mathrm{MHz}\right): \delta_{\mathrm{H}} 6.89-7.3$ $\left(3 \mathrm{H}, \mathrm{m}, \mathrm{C}_{4} \mathrm{H}_{3} \mathrm{~S}\right), 7.56$ and $7.66\left(4 \mathrm{H}, \mathrm{d}, \mathrm{C}_{6} \mathrm{H}_{4}\right)$, $5.34(1 \mathrm{H}, \mathrm{d}, \mathrm{J} 9.0 \mathrm{~Hz}, \mathrm{CH}), 5.18(1 \mathrm{H}, \mathrm{d}, \mathrm{J} 9.0 \mathrm{~Hz}$, $\mathrm{CH}), 3.50\left(2 \mathrm{H}, \mathrm{k}, \mathrm{J} 6.0 \mathrm{~Hz}, \mathrm{CH}_{2}\right), 1.29(3 \mathrm{H}, \mathrm{t}, \mathrm{J}$ $\left.6.0 \mathrm{~Hz}, \mathrm{CH}_{3}\right) \cdot{ }^{13} \mathrm{C} \mathrm{NMR}(\mathrm{CDCl} 3,75 \mathrm{MHz}): \delta_{\mathrm{C}}$ $192.02,133.90,132.16,131.96,130.34,129.23$, $128.06,127.05,126.13,65.89,49.28,15.03$.

b) To a solution of dibromo chalcone (4) ( $1 \mathrm{mmol})$ in benzene $(20 \mathrm{ml})$ was added triethylamine $(1 \mathrm{mmol})$ and ethylenediamine ( $1 \mathrm{mmol})$. The mixture was stirred at the reflux temperature of benzene for $3 \mathrm{~h}$. After completed of reaction the mixture was added to $50 \mathrm{~g}$ ice, the solid product was separated by filtration and the residue purified by crystallization from a mixture of carbon-4-chloride and hexane $1: 1$.

(Z)-2-bromo-1-(4-methylphenyl)-3-(thiophen-2-yl)prop-2-en-1-one (6). Yellow crystals, yield $77 \%, \mathrm{mp} 173{ }^{\circ} \mathrm{C} .{ }^{1} \mathrm{H}$ NMR (DMSO- $d_{6}$, $300 \mathrm{MHz}) . \delta_{\mathrm{H}} 8.26(1 \mathrm{H}, \mathrm{s},=\mathrm{CH}), 8.04(1 \mathrm{H}, \mathrm{d}$, J $6.0 \mathrm{~Hz}, \mathrm{CH}), 7.83(1 \mathrm{H}, \mathrm{d}, \mathrm{J} 6.0 \mathrm{~Hz}, \mathrm{CH}), 7.76$ (2H, d, J $8.2 \mathrm{~Hz}$, arom.), 7.67 (2H, d, J $8.2 \mathrm{~Hz}$, arom.), 7.28 (1H, t, J $6.0 \mathrm{~Hz}, \mathrm{CH}) .{ }^{13} \mathrm{C} \mathrm{NMR}$ 
(CDCl3, $75 \mathrm{MHz}) . \delta_{\mathrm{C}} 189.86,139.06,138.46$, $137.30,136.22,134.16,132.22,131.69,128.24$, $126.75,119.51$.

The procedure for syntheses of pyrazole

To a solution of dibromo chalcone (4) $(1 \mathrm{mmol})$ in $\mathrm{CH}_{3} \mathrm{CH}_{2} \mathrm{OH}(20 \mathrm{ml})$ was added triethylamine $(1 \mathrm{mmol})$ and thiosemicarbazide $(1 \mathrm{mmol})$. The mixture was stirred at the reflux temperature of ethanol for $3 \mathrm{~h}$. After completion of the reaction, the mixture was added to $50 \mathrm{~g}$ ice, the solid product was separated by filtration and the residue purified by crystallization from a mixture of carbon-4-chloride and hexane $1: 1$.

3-(4-bromophenyl)-5-(thiophen-2-yl)-1Hpyrazole-1-carbothioamide (7). Colorless crystals, yield $63 \%, \mathrm{mp} 188{ }^{\circ} \mathrm{C} .{ }^{1} \mathrm{H}$ NMR (DMSO- $\left.d_{6}, 300 \mathrm{MHz}\right) . \delta_{\mathrm{H}} 8.04(2 \mathrm{H}, \mathrm{d}, \mathrm{J} 8.2 \mathrm{~Hz}$, arom.), $7.94(1 \mathrm{H}, \mathrm{d}, \mathrm{J} 15.0 \mathrm{~Hz}, \mathrm{NH}), 7.82(1 \mathrm{H}$, d, J $6.0 \mathrm{~Hz}, \mathrm{CH}), 7.77$ (2H, d, J=8.2 Hz, arom.), $7.76(1 \mathrm{H}, \mathrm{t}, \mathrm{J} 6.0 \mathrm{~Hz}, \mathrm{CH}), 7.71(1 \mathrm{H}, \mathrm{d}, \mathrm{J} 6.0 \mathrm{~Hz}$, $\mathrm{CH}), 7.55(1 \mathrm{H}, \mathrm{d}, \mathrm{J} 15.0 \mathrm{~Hz}, \mathrm{NH}), 7.20(1 \mathrm{H}$, $=\mathrm{CH})$.

DISCUSSION OF THE RESULTS. Firstly, the chalcone derivatives 3 and $\mathbf{4}$ were synthesized by using literature methods $[10,11]$. As a result of the reactions of the thiophene-2-carboxaldehyde 1 with 4-bromoacetophenone 2 in ethanolic $\mathrm{NaOH}$ were obtained chalcone derivative 3 with good yield. Brominating of thienyl chalcone (3) with bromine in $\mathrm{CH}_{2} \mathrm{Cl}_{2}$ at room temperature resulted in selective formation of the $\alpha, \beta$-dibromo chalcone derivative 4 . Despite that thiene ring is sensitive to electrophilic substitution at its 4 and 5 positions, the brominated product of the thiene ring doesn't detect in this reaction (Scheme).<smiles>O=Cc1cccs1</smiles><smiles>CC(=O)c1ccc(Br)cc1</smiles><smiles>O=C(/C=C/c1cccs1)c1ccc(Br)cc1</smiles><smiles>O=C(c1ccc(Br)cc1)C(Br)C(Br)c1cccs1</smiles><smiles>COC(C(=O)c1ccc(Br)cc1)C(Br)C(Br)c1cccs1</smiles>

Scheme. The synthesis route of compounds 37 
The structures of known compounds ( 3 and 4) were established based on spectral data and comparison with literature data $[10,11]$.

At next stage of this work, the reaction of $\alpha$, $\beta$-dibromo ketone 4 with equivalence amount of triethylamine, ethylenediamine mixture in refluxing temperature of ethanol and benzene have been carried out. In ethanolic solution interaction of solvent with the $\alpha, \beta$-dibromo ketone gave to $\alpha$-ethoxy- $\beta$-bromo-ketone $\mathbf{5}$ (fig. 1 and 2), in benzene solution the formation of regioselective $\alpha$-bromo-chalcone 6 observed (fig. 3 and 4). It is important to note, the presences of asymmetric centers in the compo- und of 5 lead to a doubling of the signals in ${ }^{1} \mathrm{H}$, ${ }^{13} \mathrm{C}$ spectra, which it is very interesting in terms of NMR spectroscopy (fig. 1 and 2).

At the final stage of this study, the reaction of $\alpha, \beta$-dibromo ketone 4 with equivalence amount of triethylamine, thiosemicarbazone mixture in refluxing temperature of ethanol (or benzene) lead to new pyrazole derivative 7 (fig. 5).

The formation of pyrazole derivatives by refluxing of $\alpha, \beta$-dibromo ketone 4 with the phenyl hydrazine or 2,4-dinitrophenylhydrazine in ethanolic and benzene solutions wasn't observed.

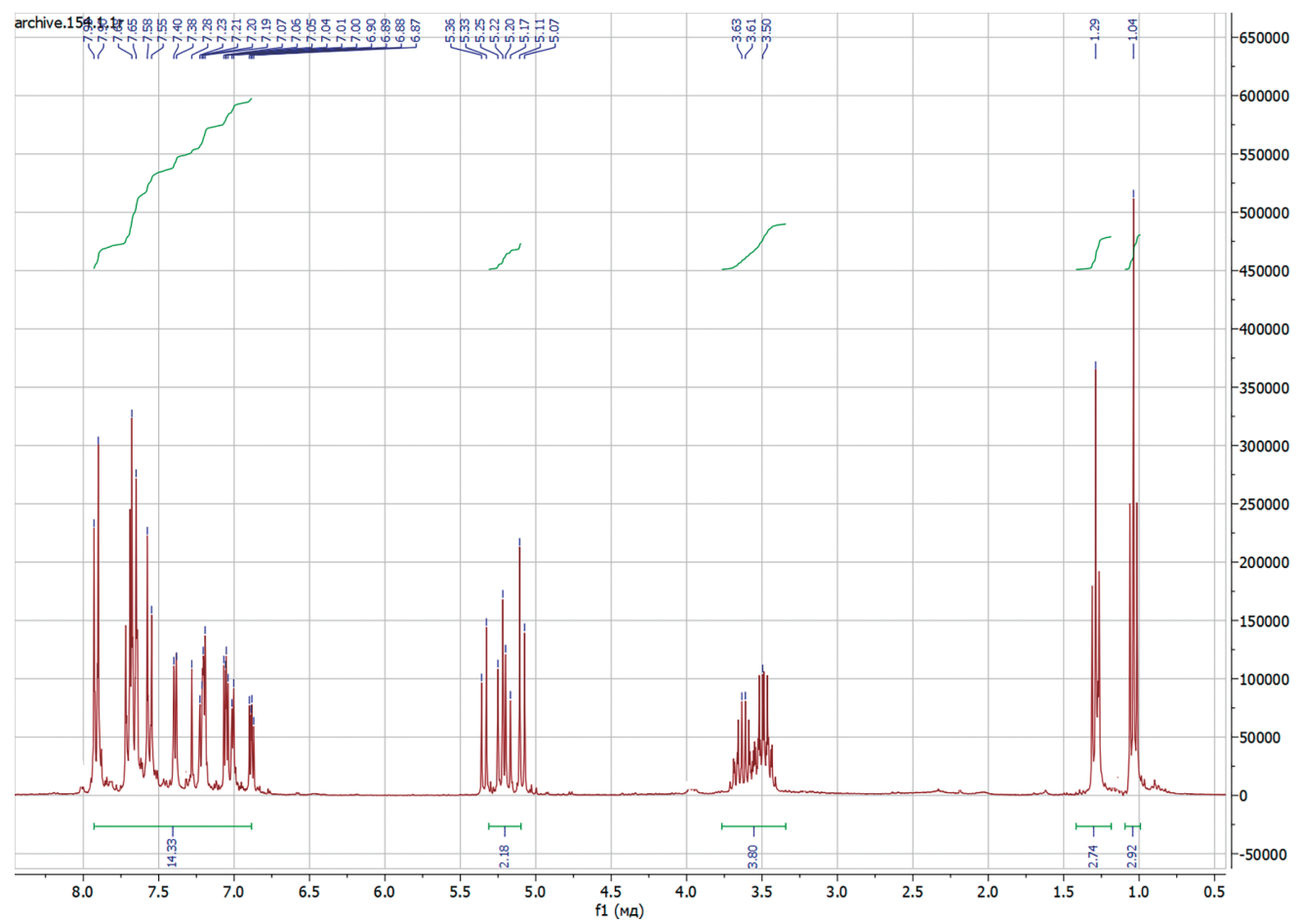

Fig. 1. ${ }^{1} \mathrm{H}$ NMR contour plot of 5 in $\mathrm{CDCl}_{3}$. 


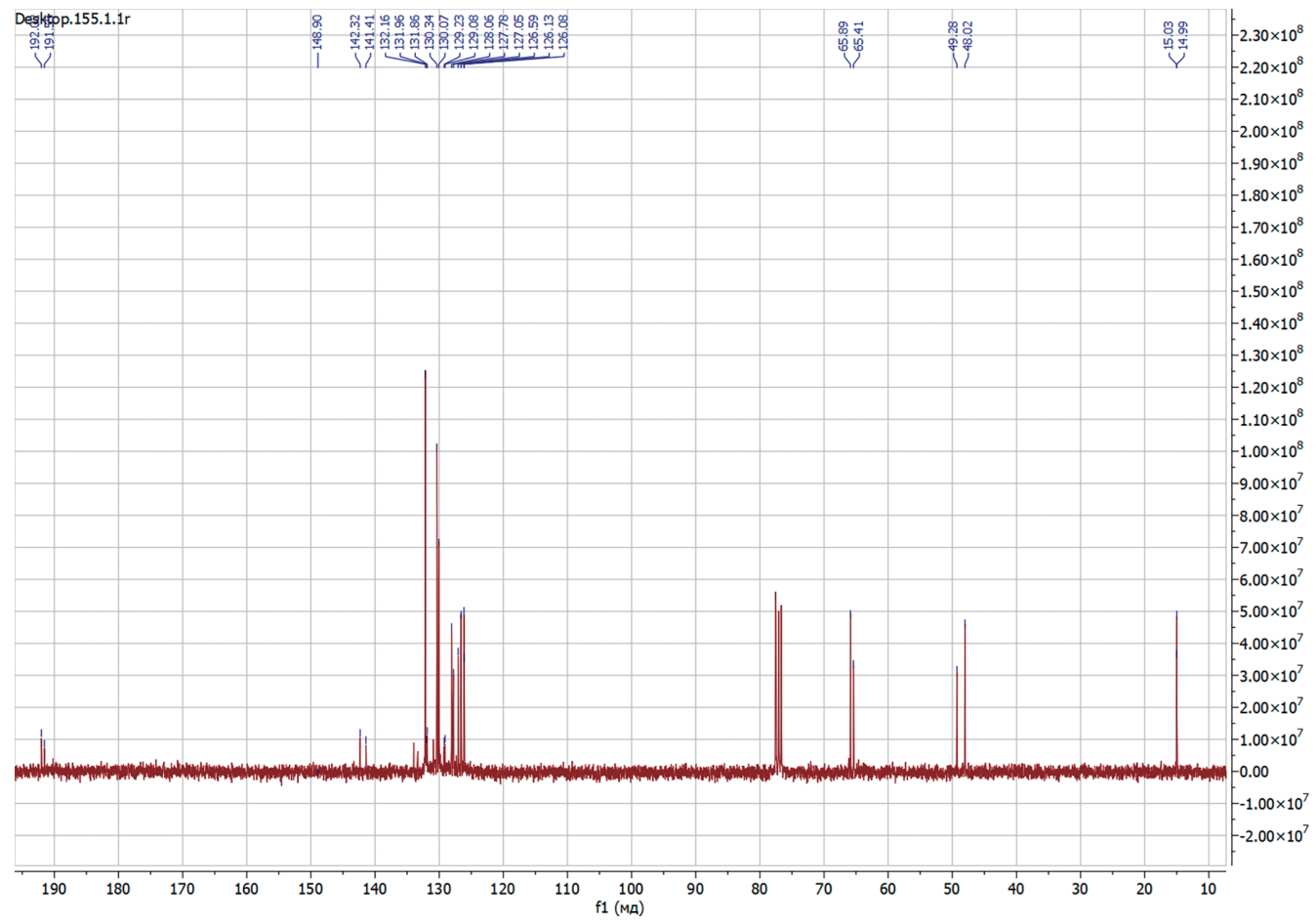

Fig. 2. ${ }^{13} \mathrm{C}$ NMR contour plot of 5 in $\mathrm{CDCl}_{3}$.

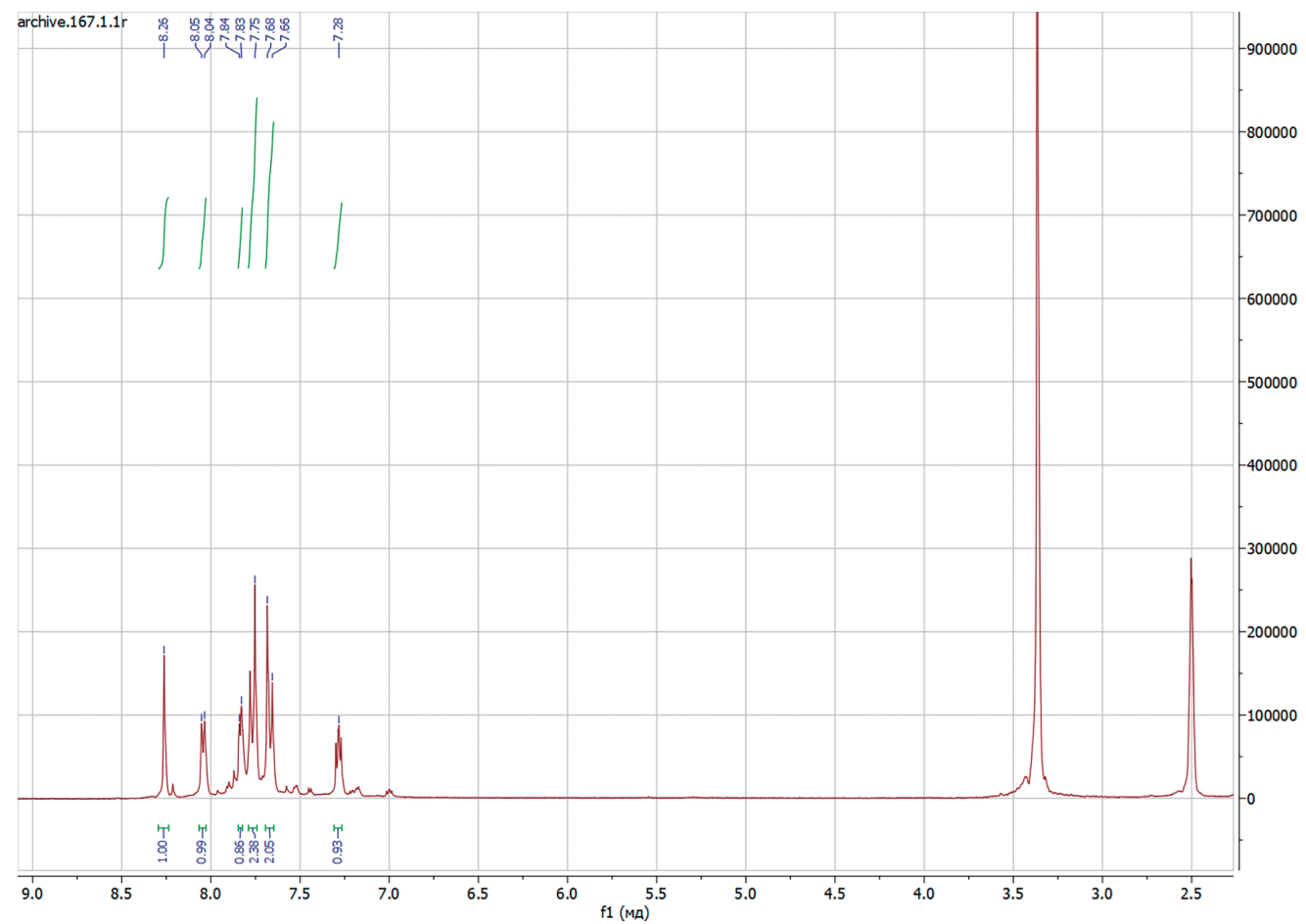

Fig. 3. ${ }^{1} \mathrm{H}$ NMR contour plot of 6 in DMSO- $\mathrm{d}_{6}$. 


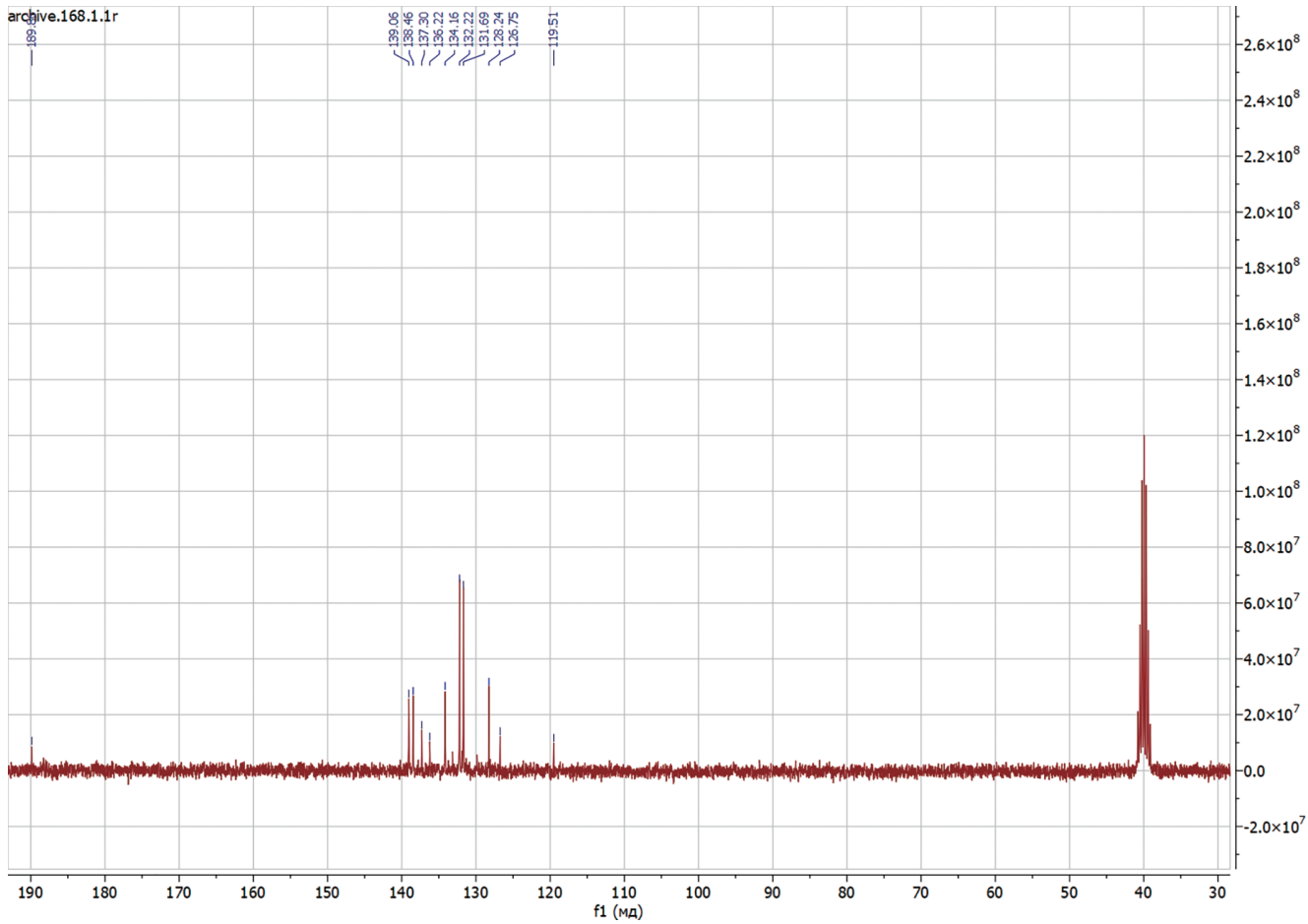

Fig. 4. ${ }^{13} \mathrm{C}$ NMR contour plot of 6 in DMSO-d .

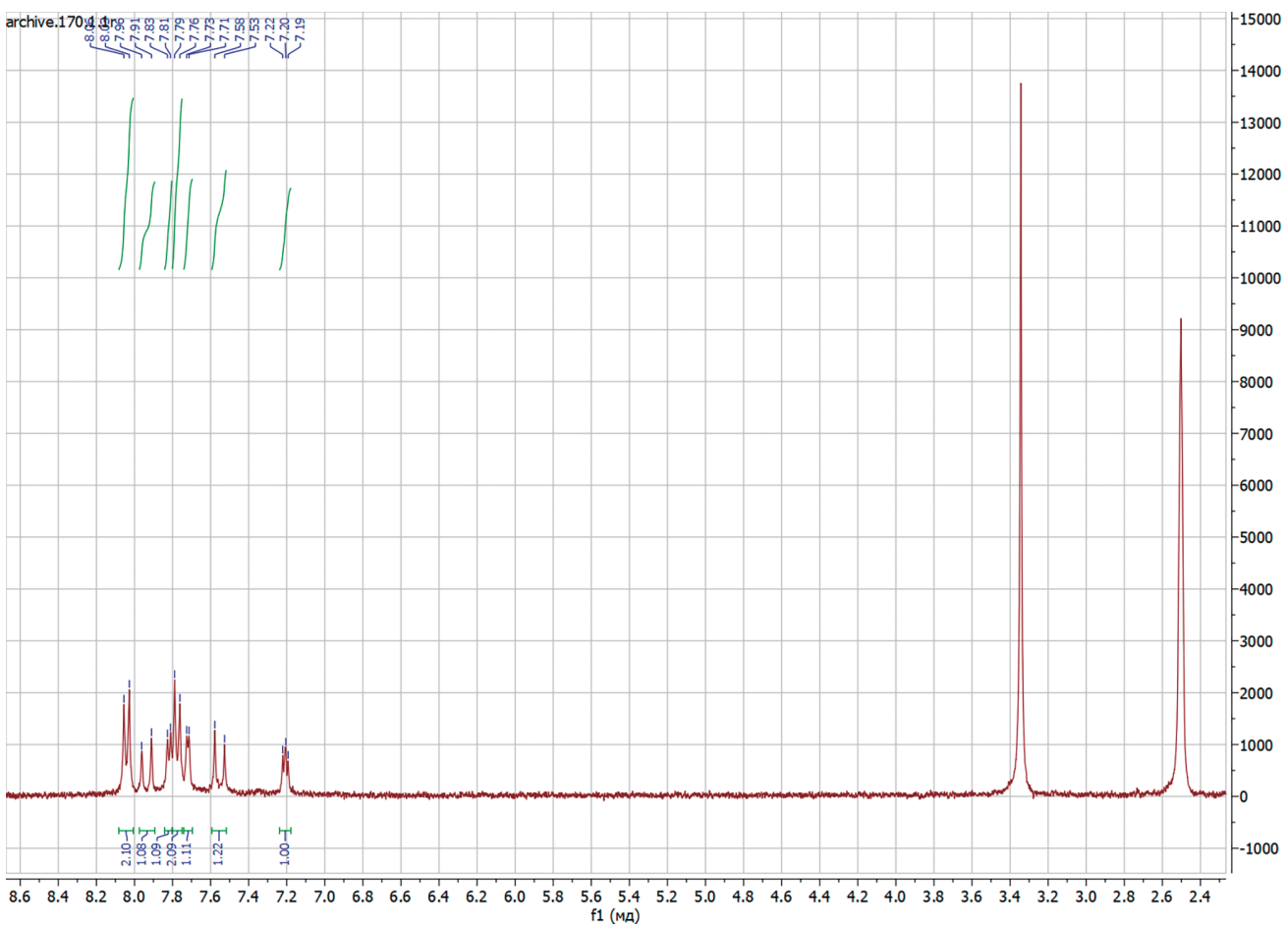

Fig. 5. ${ }^{1} \mathrm{H}$ NMR contour plot of 7 in DMSO-d $\mathrm{d}_{6}$. 
CONCLUSIONS. In summary, a new $\alpha$-ethoxy- $\beta$-bromo-ketone, $\alpha$-bromo chalcone and pyrazole derivatives have been prepared in good yields by the reactions of $\alpha, \beta$-dibromo ketone with triethylamine, ethylenediamine or triethylamine thiosemicarbazone mixture in different reaction conditions.

We would like to note that the reported results have never been presented before.

ВИВЧЕННЯ РЕАКЦІї $\alpha, \beta$-ДИБРОМКЕТОНУ В ПРИСУТНICТІ ДЕЯКИХ АМІНIB

\section{I. Г. Мамедов ${ }^{a \star}$, I. М. Шихалієва ${ }^{a}$,} Ю. В. Мамедова

Бакинський державний університет, хімічний факультет, вул. Акад. 3. Халілова 23, Баку, Азербайджан

У результаті реакцій $\alpha, \beta$-дибромкетону $з$ сумішшю триетиламіну, етилендіаміну або триетиламіну тіосемікарбазону за різними реакційними умовами було отримано з добрими виходами нові $\alpha$-етокси- $\beta$-бромокетон, $\alpha$-бромхалкон та похідні піразолу. Cелективна реакція дегідробімування $\alpha, \beta$-дибромкетону в присутності різних амінів у розчині бензолу та $\alpha$-етокси- $\beta$-бром-кетону в етанолі дозволила отримати значну кількість $а$-бром-халкону зі вмістом тієнового кільця. Методами ЯМР встановлено, що реакція $\alpha, \beta$-дибромкетону з тіосемікарбазидом призводить до утворення нового похідного піразолу.

Ключові слова: ацетофенон, халкон, $\alpha, \beta$-дибромкетон, піразол.

\section{REFERENCES}

1. Saikia I., Borah A.J., Phukan P. Use of bromine and bromo-organic compounds in organic synthesis. Jour. Chem. Rev., 2016. 12: 6837.

2. Abdel-Rahman A.A.-H., Abdel-Megied A.E.-S., Hawata M.A.-M., Kasem E.R., Shabaan M.T. Synthesis and antimicrobial evaluation of some chalcones and their derived pyrazoles, pyrazolines, isoxazolines, and 5,6-dihydropyrimidine-2-(1H)-thiones. Monatshefte fur Chemie. 2017. 138: 889.

3. Samshuddin S., Butcher R. J., Akkurt M. Narayana B., Yathirajan H. S., Sarojini B. K. 1,3-Bis(4-fluorophenyl)-N,N'-(propane1,3-diylidene)dihydroxylamine. Acta Crystallogr Sect E. 2011. E67: O1954.

4. Mamedov I.G., Mamedova Y.V., Khrustalev V.N, Bayramov M.R, Maharramov A.M. Dependence of biological activities of some chalcone derivatives from the molecular structure. Ind. J. Chem., 2017. 56B: 192.

5. Mamedov I.G., Maharramov A.M., Bairamov M.R, Mamedova Y.V. Investigation of the molecular dynamics of some phenols and their acetyl isomers in solutions by NMR relaxation. Russ. Jour. Phys. Chem. 2010. 12: 2182.

6. Mamedov I.G., Bayramov M.R., Mamedova Y.V., Maharramov A.M. Molecular dynamics of 6-methyl-2-phenyl-2,3-dihydro-4H-chromen-4-one and 6-methyl-2-(4-nitrophenyl)-2,3-dihydro-4Hchromen-4-one (flavanone) derivatives in a solution studied by NMR spectroscopy. Jour. Magn. Reson. Chem. 2013. 53: 234.

7. Budak Y., Ceylan M. Synthesis and 
characterization of $\alpha$ - bromo chalcone derivatives. Chine. Jour. Chem. 2009. 8: 1575.

8. Parveen H., Prince Firdoos Iqbal P.F., Azam A. Synthesis and characterization of a new series of hydroxy pyrazolines. Jour. Synt. Commun., 2008. 38: 3973.

9. Ray J. Butcher R.J., Yathirajan H. S., Anilkumar H. G., Sarojinic B. K., Narayanad B. 2-Bromo-1-(4-methylphenyl)-3-[4-(methylsulfanyl)phenyl] prop-2-en-1-one. Acta Crystallogr Sect E. 2006. 62: o1659.

10. Zheng C.J., Jiang S.M., Chen Z.H., Ye B.J., Piao H.R. Synthesis and antibacterial activity of some heterocyclic chalcone derivatives bearing thiofuran, furan, and quinoline moieties. Jour. Arch. Pharm. Chem., 2011. 344: 689.

11. Roman G. Critical assessment of two classical synthetic methods for preparation of thiophene-substituted isoxazoles. Jour. Res. Chem. Intermed. 2013. 40: 2039.

12. Karthikeyan M.S., Holla B.S., Kumari N.S. Synthesis and antimicrobial studies on novel chloro-fluorine containing hydroxy pyrazolines. Eur. J. Med. Chem. 2007. 42: 30.

13. Sarojini B.K., Vidyagayatri M., Darshanraj C.G., Bharath B.R., Manjunatha H. $\mathrm{DPPH}$ scavenging assay of novel 1,3-disub-
stituted-1H-pyrazol-5-ols and their in-silico studies on some proteins involved in alzheimers disease signaling cascade. Jour. Lett. Drug Des. Disc. 2010. 7:. 214.

14. Amir M., Kumar H., Khan S. A. Synthesis and pharmacological evaluation of pyrazoline derivatives as new anti-Inflammatory and analgesic agents. Jour. Bioorg. And Med. Chem. Lett., 2008. 3: 918.

15. Karthikeyan M. S., Holla B. S., Kumari N. S. Synthesis and antimicrobial studies on novel chloro-fluorine containing hydroxy pyrazolines. Jour. Eur. J. Med. Chem., 2007. 42: 30 .

16. Manna F., Chimenti F., Fioravanti R., Bolasco A., Seecci D., Chimenti P., Ferlini C., Scambia G. Synthesis of some pyrazole derivatives and preliminary investigation of their affinity binding to P-glycoprotein. Jour. Bioorg. Med. Chem. Lett., 2005. 15: 4632.

17. Antúnez M.M.C., LGonzález M.L., Razo-Hernández R.S., Alvarez L. Design, synthesis and QSAR study of 2'-hydroxy$4^{\prime}$-alkoxy chalcone derivatives that exert cytotoxic activity by the mitochondrial apoptotic pathway. Jour. Bioorg. Med. Chem., 2019. 1: 43.

Стаття надійшла 05.02.2020. 